\title{
Methodological approaches to infer end-of-winter snow distribution on alpine glaciers
}

\author{
Leo SOLD, ${ }^{1 *}$ Matthias HUSS, ${ }^{1}$ Martin HOELZLE, ${ }^{1}$ Hubert ANDEREGGEN, ${ }^{2}$ \\ Philip C. JOERG, ${ }^{3}$ Michael ZEMP $^{3}$ \\ ${ }^{1}$ Department of Geosciences, University of Fribourg, Fribourg, Switzerland \\ E-mail: leo.sold@unifr.ch \\ ${ }^{2}$ Airborne Scan AG, Visp, Switzerland \\ ${ }^{3}$ Department of Geography, University of Zürich, Zürich, Switzerland
}

\begin{abstract}
Snow accumulation is an important component of the mass balance of alpine glaciers. To improve our understanding of the processes related to accumulation and their representation in state-ofthe-art mass-balance models, extensive field measurements are required. We present measurements of snow accumulation distribution on Findelengletscher, Switzerland, for April 2010 using (1) in situ snow probings, (2) airborne ground-penetrating radar (GPR) and (3) differencing of two airborne light detection and ranging (lidar) digital elevation models (DEMs). Calculating high-resolution snow depth from DEM-differencing requires careful correction for vertical ice-flow velocity and densification in the accumulation area. All three methods reveal a general increase in snow depth with elevation, but also a significant small-scale spatial variability. Lidar-differencing and in situ snow probings show good agreement for the mean specific winter balance $(0.72$ and $0.78 \mathrm{~m}$ w.e., respectively). The lidar-derived distributed snow depth reveals significant zonal correlations with elevation, slope and curvature in a multiple linear regression model. Unlike lidar-differencing, GPR-derived snow depth is not affected by glacier dynamics or firn compaction, but to a smaller degree by snow density and liquid water content. It is thus a valuable independent data source for validation. The simultaneous availability of the three datasets facilitates the comparison of the methods and contributes to a better understanding of processes that govern winter accumulation distribution on alpine glaciers.
\end{abstract}

\section{INTRODUCTION}

Temporal changes in glacier mass balance are known to be an excellent indicator for changing climatic conditions (Haeberli and Beniston, 1998; Kaser and others, 2006; Solomon and others, 2007). The impacts of future changes in climate forcing on mass balance and runoff from glacierized catchments are the subject of intense research (e.g. Huss, 2011; Farinotti and others, 2012; Salzmann and others, 2012). Models are used to assess these impacts and provide general conclusions from a small subset of monitored glaciers (Zemp and others, 2009).

Presently, there is a wide range of mass-balance models available that cover ablation processes to all degrees of complexity (Hock, 2005, and references therein). To compute annual glacier mass balance all models need, aside from the ablation processes, to account for the amount and spatial distribution of snow accumulation. Typically, accumulation is estimated from precipitation measurements at nearby weather stations, gridded precipitation climatologies or climate model outputs that are tuned to site characteristics, usually by applying an elevation gradient and temperature threshold for snowfall (Hock, 1999; Machguth and others, 2006a, 2009). However, this is a weak representation of the actual snow accumulation pattern. Aside from avalanches, the interplay of topography and wind leads to strong variations in the spatial distribution of snow depth (Liston and Sturm, 1998; Winstral and Marks,

*Present address: Department of Geosciences, Geography Unit, University of Fribourg, Fribourg, Switzerland.
2002; Machguth and others, 2006b; Lehning and others, 2008; Dadic and others, 2010a). Due to the complexity of the physical modelling of preferential snow deposition and redistribution processes, and due to the difficulties inherent in the measurement of solid precipitation in high-alpine terrain, the accumulation part of state-of-the-art massbalance models is much less developed than the description of melting processes (e.g. Dadic and others, 2010a). Improving the level of understanding with regard to the accumulation of snow on alpine glaciers is a prerequisite for strengthening the physical justification of the accumulation modules of mass-balance models (Machguth and others, 2006b). To date, only a few studies have tackled this issue by providing the necessary extensive end-of-winter snow depth distribution measurements (Machguth and others, 2006b; Dadic and others, 2010a,b). However, evaluating the accuracy of the estimated spatial distribution requires separate reference data to be available.

The spatial distribution of snow depth is commonly measured by time-consuming in situ probings that provide point values and can have large uncertainties in accumulation zones where locating the previous summer surface can be challenging. Other possible approaches are groundpenetrating radar (GPR) and differencing of digital elevation models (DEMs). GPR provides a non-destructive method for various purposes in glaciology. This is supported by the low conductivity and, hence, the deep penetration of the signal into snow and ice at $\mathrm{MHz}$ frequencies. The signal is reflected from boundaries with a contrast in dielectric permittivity that can be related to a change in material properties (e.g. from ice to bedrock, variations in density, impurities such as dust 


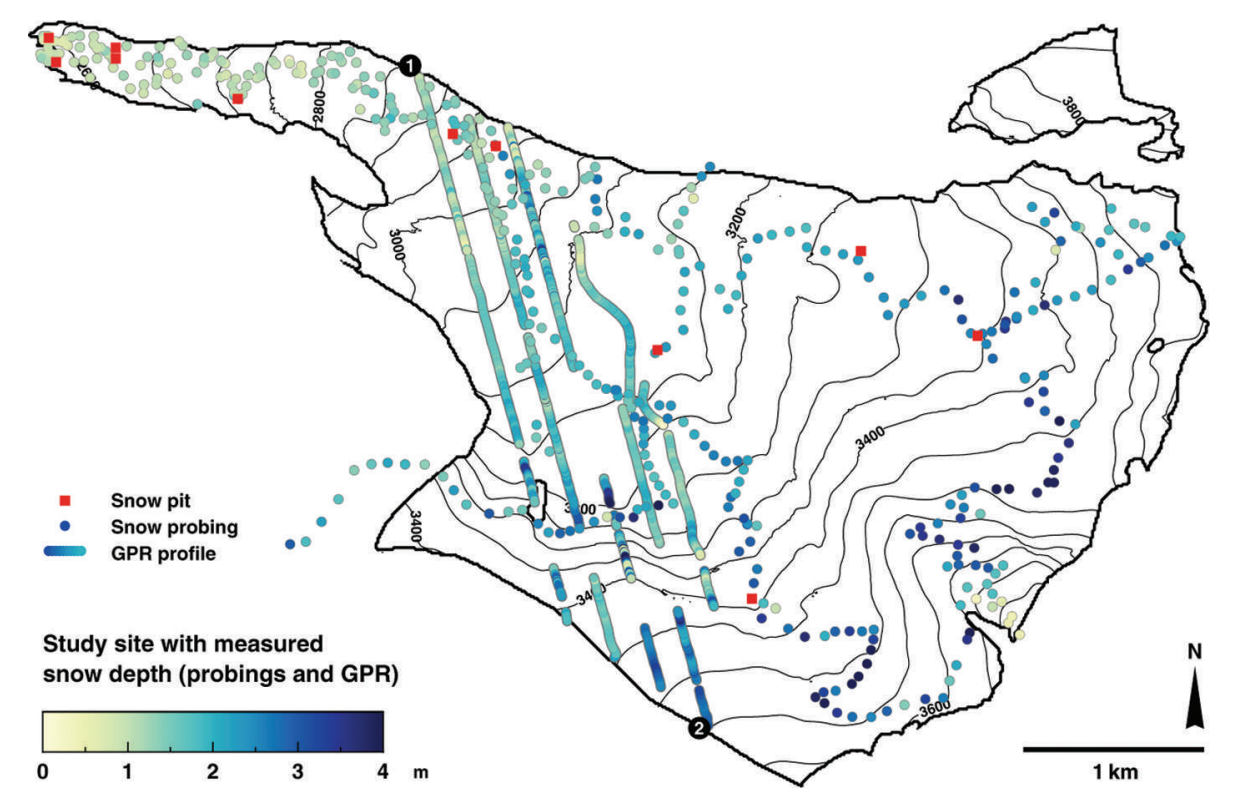

Fig. 1. Map of the study site: Findelengletscher, Valais, Switzerland. Dots show manual snow probings, lines represent GPR profiles, the colour code shows measured snow depth in April 2010.

or ash, or water content (Ulriksen, 1982; Plewes and Hubbard, 2001)). Since the 1960s this has been used for ground-based or airborne detection of ice thickness (Robin and others, 1969; Bauder and others, 2003; Damm, 2004; Lalumiere and Prinsenberg, 2009) or internal layers within snow and firn (Kohler and others, 1997; Kanagaratnam and others, 2004; Dunse and others, 2009; Heilig and others, 2010). Radar-based surveys of snow accumulation distribution have focused on ice sheets (Helm and others, 2007; Dunse and others, 2008; Eisen and others, 2008; Kruetzmann and others, 2011) and snow on the ground (Marchand and others, 2003; Yankielun and others, 2004; Marshall and Koh, 2008). For mapping snow accumulation on alpine glaciers, however, the airborne application of GPR has only been addressed by Machguth and others (2006b), although results show that it can be a highly effective tool, especially in remote and inaccessible areas.

More attention has been paid to the use of DEMdifferencing to assess changes in glacier mass balance (Arendt and others, 2002; Bamber and Rivera, 2007; Abermann and others, 2010; Kääb and others, 2012). Light detection and ranging (lidar) scanning systems offer a highprecision tool for range measurements, that has been applied for $\sim 20$ years. The travel time of a laser pulse from emission until reflection from a target and return to a detector, coupled with the speed of light in the air conditions, provides a measure for the distance between the sensor and the illuminated spot. In airborne applications, the exact position and orientation of the aircraft are necessary to locate the ground points, which are then interpolated to the regular grid of a DEM (Ackermann, 1999; Wehr and Lohr, 1999). In our study, repeated lidar DEMs of Findelengletscher, Switzerland (Joerg and others, 2012), provide spatially distributed elevation changes between autumn and spring. To obtain distributed snow depth over glaciated surfaces, this requires corrections of the vertical ice velocity and firn compaction in the surface differencing scheme. Such corrections have not been realized so far, although studies indicate their need (Dadic and others, 2010a,b; Helfricht and others, 2012, 2013).
In this study we discuss simultaneous measurements of snow accumulation distribution on an alpine valley glacier, using the traditional glaciological approach of in situ snow probings and snow density pits, helicopter-borne GPR measurements of the snow depth and surface elevation changes given by differencing of two lidar DEMs. Snow probings and DEM-differencing provide the winter mass balance of Findelengletscher. Furthermore, we show how the geodetically derived snow depth distribution can be corrected for the vertical ice velocity and firn compaction, based on the in situ probings and long-term mass-balance and geometry changes. The result is a fully distributed dataset that is validated with the GPR measurements and correlated against elevation, surface slope and curvature. Analysis of the three datasets provides new insights into the ability of the utilized methods to correctly represent snow depth, and contributes to a better understanding of processes that govern winter accumulation of alpine glaciers.

\section{STUDY SITE AND FIELD DATA}

Findelengletscher is a large temperate valley glacier $\left(13.0 \mathrm{~km}^{2}\right)$ in Valais, Switzerland. It is northwesterly exposed and covers an elevation range from 2600 to 3900 ma.s.l. (Fig. 1). Situated directly below the main ridge, local precipitation largely depends on the wind direction. The accumulation area strongly benefits from south- and southeasterly conditions. A glacier mass-balance monitoring programme was started in 2004 (Machguth, 2008). Annual mass balance is determined with a network of 13 ablation stakes and two snow density pits. On average, the measurements indicate a negative mass balance (Joerg and others, 2012), leading to a continued retreat of the glacier snout (Glaciological Reports, 2011). Glaciological measurements of seasonal mass balance from snow probings and density profiles combined with repeated terrestrial snowline photographs are available from 2009 (Huss and others, 2013).

The conventional method of vertically probing the underlying ice (or last summer) surface through the snowpack provides a direct measurement of snow depth as a 
point value (Østrem and Brugman, 1991). The probe measurements were carried out on 10-11 April 2010. For practical reasons, they were taken along the walking paths leading from the upper accumulation area to the tongue of Findelengletscher (Fig. 1). In its accumulation area the boundary between snow and firn is typically made up of a clearly defined ice lens of variable thickness, that often can be unambiguously detected with a probe. However, careful probing is necessary to avoid misinterpretation of internal ice layers within the snow cover. The entire glacier elevation range was covered by 403 probings (Fig. 2), each of which was made up of two to five averaged probings to account for outliers (crevasses) and small-scale variability. Mean snow depth from all probings was $1.86 \mathrm{~m}$, and the standard deviation within multiple measurements at a given location was $0.13 \mathrm{~m}$. The measured snow depth was elevationdependent but highly variable (Fig. 2).

Additionally, the bulk density of a snow column was measured in 11 snow pits across the glacier. Values ranged from 223 to $294 \mathrm{~kg} \mathrm{~m}^{-3}$ on the glacier tongue to $407 \mathrm{~kg} \mathrm{~m}^{-3}$ at the centre of the glacier $(3130 \mathrm{~m}$ a.s.I.). This probably represents (1) different process regimes in snowpack evolution, involving wind effects on initial deposition, erosion and redeposition of snow and/or (2) differences in the prevalent processes of snow metamorphism. While the internal vertical variability of the snow density was not covered by the sampling scheme, multiple bulk measurements were taken at ten of the snow pits. Standard deviation within measurements at these locations was $21 \mathrm{~kg} \mathrm{~m}^{-3}$. Density was averaged over $100 \mathrm{~m}$ elevation bands. For bands that were not covered by at least one measurement, the average of neighbouring bands was used. Weighting density according to the area of the respective elevation bands revealed a spatial mean snow density of $362 \mathrm{~kg} \mathrm{~m}^{-3}$. To follow the ongoing monitoring programme of seasonal mass balance of Findelengletscher we applied an enhanced traditional extrapolation scheme to the snow probings, to obtain snow depth on a $25 \mathrm{~m} \times 25 \mathrm{~m}$ resolution grid. It is based on a distance-weighted average of probings within a radius of $400 \mathrm{~m}$ around each gridpoint. If fewer than three measurements were available, the search radius was increased. Additionally, we superimposed small-scale snow depth variability due to local effects that might not be captured by the spatially discontinuous probings. According to a procedure described by Huss and others (2008), snow depths were decreased over steep slopes $\left(>40^{\circ}\right)$ and convex terrain shapes, whereas they were increased for concave surfaces. These corrections are relatively small for the central parts of the glacier, but are important to yield realistic snow depths for regions prone to avalanching and wind erosion.

The GPR system was a Noggin 500 (Sensors \& Software Inc., Canada) that operated a shielded antenna with a centre frequency of $500 \mathrm{MHz}$. It was directly mounted on the bottom of a helicopter. Traces were recorded with a constant time increment of $0.1 \mathrm{~s}$ at a waveform sampling interval of $0.2 \mathrm{~ns}$. Their position was provided by a synchronized GPS with a horizontal accuracy of 1-5 m. On 10-11 April, $\sim 12000$ traces were recorded with the helicopter flying at $\sim 10 \mathrm{~m} \mathrm{~s}^{-1}$ and $5-10 \mathrm{~m}$ above ground. The angle of beam spread is $45^{\circ}$ and $60^{\circ}$ perpendicular and along the flight direction, respectively. Hence, the footprint size at the snow surface is less than $8 \mathrm{~m} \times 12 \mathrm{~m}$. The survey covered $12.7 \mathrm{~km}$ of linear tracks in ten profiles between 2900 and $3550 \mathrm{~m}$ a.s.I. across the glacier (Fig. 1). In an airborne



Fig. 2. Measured snow depth from 403 probings in April 2010.

application of the GPR system the risk of interference with other essential and safety-of-life radio services is high. A special licence for the campaign was granted by the Swiss telecommunication regulator (OFCOM).

Lidar surveys were carried out on 4 October 2009, while the ablation area of Findelengletscher $(<3200 \mathrm{~m}$ a.s.l. $)$ was snow-free, and on 10 April 2010 at the end of the accumulation season. The Optech ALTM 3100 scanning system was mounted to a Pilatus Porter fixed-wing aircraft equipped with differential GPS and an inertial measurement unit to derive its position and orientation. Average point density was 7.6 and $8.1 \mathrm{~m}^{-2}$, respectively. Joerg and others (2012) describe the geo-referencing, point cloud interpolation and generation of the grid $(1 \mathrm{~m} \times 1 \mathrm{~m}$ cell size $)$ in further detail and provide an extensive uncertainty assessment. Standard deviation on reference surfaces was $0.09 \mathrm{~m}$ (October 2009) and $0.19 \mathrm{~m}$ (April 2010, reference surfaces snow-covered). Additionally, longer-term geometry change is given by two lidar DEMs from similar surveys on 28-29 October 2005 and 29 September 2010.

\section{METHODS \\ Processing of GPR data}

Many processing techniques for GPR data have been adopted from seismic reflection surveys that have a similar principle (Davis and Annan, 1989; Fisher and others, 1996). Since the selection of processing steps and their parameter settings depend strongly on field conditions, survey design and intention, no universal procedure is available (Ulriksen, 1982; Fisher and others, 1996; Annan, 1999). In the given order, the following processing steps were found to sufficiently improve the helicopter-borne GPR data quality:

1. Spatial interpolation; correction for variations in the helicopter's velocity. Traces were interpolated linearly to an equidistant spacing of $1 \mathrm{~m}$.

2. Frequency bandpass $300-1000 \mathrm{MHz}$; the high-pass filter removed bending and constant offset of the signal while the low-pass filter removed high-frequency speckle and noise (Jol, 2009). 




Fig. 3. First $1500 \mathrm{~m}$ of GPR profile 1 which lie in the ablation area (Fig. 1) after processing. (a) The reflection of the interface between air and snow. (b) The reflection of the interface between snow and glacier ice. The green markers indicate a crevassed area in the centre of the glacier.

3. Background removal; subtracting the average over the distance domain from all traces in the profile reduced the effects of signal ringing and the airwave.

4. Gain function, linear and exponential; to account for signal attenuation with depth.

Migration did not improve the data quality and was not applied. For all measured radar profiles these processing steps allowed the the air/snow interface and the snow/firn or snow/ice interface to be distinguished without the help of separate snow depth data (Fig. 3). The reflectors were marked in the processing software (Reflexw, Sandmeier Scientific Software) either manually or semi-automatically with a built-in phase-following tool. To convert the difference in two-way travel time between the two marked reflectors from the time to the depth domain, an assumption for the radar wave velocity is required. Density and liquid water content strongly affect the dielectric properties of snow and several empirical formulas exist to compute the permittivity (Kovacs and others, 1993; Frolov and Macheret, 1999). According to Frolov and Macheret (1999), we obtained the relative permittivity, $\varepsilon_{\mathrm{d}^{\prime}}^{\prime}$ of dry snow from the mean measured density, $\rho=362 \mathrm{~kg} \mathrm{~m}^{-3}$, as

$$
\varepsilon_{\mathrm{d}}^{\prime}=(1+0.857 \rho)^{2} \text {. }
$$

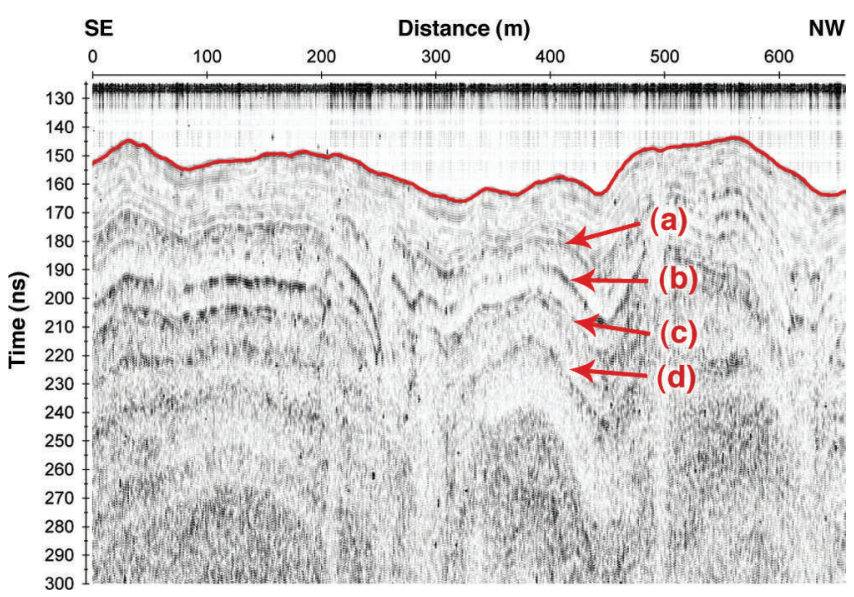

Fig. 4. GPR profile 2 which lies in the accumulation area (Fig. 1), after processing with reflectors of the snow surface (marked) and (a-d) annual summer surfaces.
The mean radar wave velocity, $u$, was then computed as $u=c \cdot\left(\varepsilon_{\mathrm{d}}^{\prime}\right)^{-0.5}=0.229 \mathrm{mns}^{-1}$. This constant value was used to derive snow depth from the reflectors in the GPR profiles. However, uncertainties and variations in snow density directly affect $u$ and, therefore, the conversion from travel time to snow depth. Further, we assume that the snowpack was dry. This is in line with observations during fieldwork, except for the glacier tongue that was not covered by GPR profiles. An analysis of the related errors is given in the Discussion.

The $500 \mathrm{MHz}$ antenna also resolved some internal layering of the snowpack. In the accumulation area of Findelengletscher, several firn layers from previous years could be distinguished (Fig. 4). While the 2009 surface could still be determined consistently, the successive dating of the earlier summer surfaces remained speculative. The penetration depth of the GPR signal depends on the height of the helicopter above ground and the physical properties of the subsurface. In the accumulation area we found reflections from down to $20 \mathrm{~m}$ below the snow surface.

\section{Geodetic elevation change from lidar DEMs}

In a first-order approach, the elevation change of each gridcell was interpreted as snow accumulation (Grünewald and others, 2010; Egli and others, 2012; Helfricht and others, 2012). The resulting pattern of maximal snow depths on the glacier tongue and small snow depths in the accumulation area (Fig. 5) was, however, inconsistent with in situ snow probings that revealed increasing snow depth with elevation (Fig. 2). The principle of comparing two DEMs of different dates makes this approach sensitive to secondary processes that alter the glacier surface elevation. This involves (1) the vertical displacement of the ice surface as part of the glacier flow, hereafter referred to as the emergence velocity, which is positive (emergence) in the ablation area and negative (submergence) in the accumulation area, (2) surface lowering due to firn compaction in the accumulation area and (3) surface lowering from melt after the acquisition of the October 2009 DEM. The formation of superimposed ice on the summer surface is assumed to be negligible in our case, due to the temperate nature of Findelengletscher.

The ice emergence velocity affects the measured surface elevation change as the glacier moves during the time-span between the two generated DEMs (Helfricht and others, 


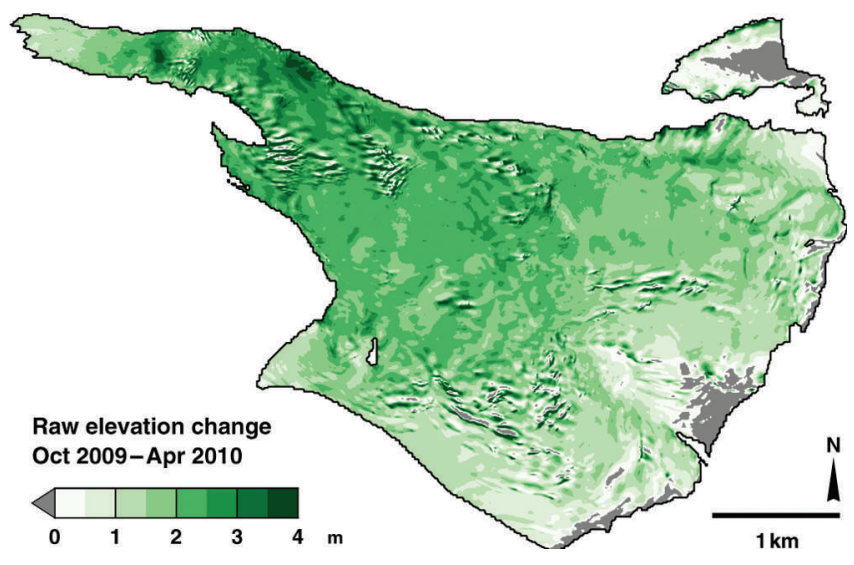

Fig. 5. Raw lidar-derived elevation change from October 2009 to April 2010. Grey shading indicates negative values.

2012, 2013). For a glacier that is in balance with climatological and all other forcings, this vertical component of glacier flow is equal to the reversed local annual massbalance rate, $-b_{\mathrm{a}}$, divided by the density of ice, $\rho_{\text {ice. }}$ In the accumulation area, the compaction of firn, $v_{\text {firn }}$, adds to the glacier surface elevation change. A potential imbalance of mass balance and ice flow can be accounted for with the observed annual geometry changes, $\Delta z$. The annual vertical displacement, $v_{z}$, of the last summer surface is derived for fixed points, $(x, y)$, on the glacier surface. Thus, it is not affected by horizontal flow and slope (Cuffey and Paterson, 2010) and can be written as

$$
v_{\mathrm{z}}=v_{\mathrm{z}}(x, y)=\Delta z-\frac{b_{\mathrm{a}}}{\rho_{\text {ice }}}+v_{\text {firn }}
$$

where positive values point upwards (emergence), and negative values indicate a lowering of the surface (submergence). Over the cycle of one hydrological year and integrated over the whole firn column, one annual accumulation layer is transformed from snow to ice. At the top of the firn column this results in a surface lowering of

$$
v_{\text {firn }}=b_{\mathrm{a}} \cdot\left(\rho_{0}^{-1}-\rho_{\text {ice }}^{-1}\right),
$$

with $\rho_{0}$ as the initial firn density. Equations (2) and (3) can be combined to give

$$
v_{\mathrm{z}}=\Delta \mathrm{z}-\frac{b_{\mathrm{a}}}{\rho},
$$

with $\rho=\rho_{\text {ice }}$ in the ablation area and $\rho=\rho_{0}$ in the accumulation area. For the initial firn density we set $\rho_{0}=550 \mathrm{~kg} \mathrm{~m}^{-3}$ as an average from repeated measurements in previous years. Density of glacier ice was set to $\rho_{\text {ice }}=900 \mathrm{~kg} \mathrm{~m}^{-3}$.

The annual mass balance of every cell of a $25 \mathrm{~m} \times 25 \mathrm{~m}$ resolution grid for the hydrological years 2005/06 to 2009/10 was evaluated using a distributed accumulation and melt model (Huss and others, 2009), that was tuned to the in situ mass-balance measurements of each year individually. In this model, the spatial variations in annual mass balance for unmeasured regions of the glacier are given by a description of physical processes (Fig. 6a). The geodetic geometry change was available for the same period from differencing of two lidar DEMs. By annually averaging the mass balance and geometry changes for all years of the geodetic survey, $\overline{b_{a}}$ and $\overline{\Delta z}$ were obtained. The spatially integrated estimation of the emergence velocity is equal to
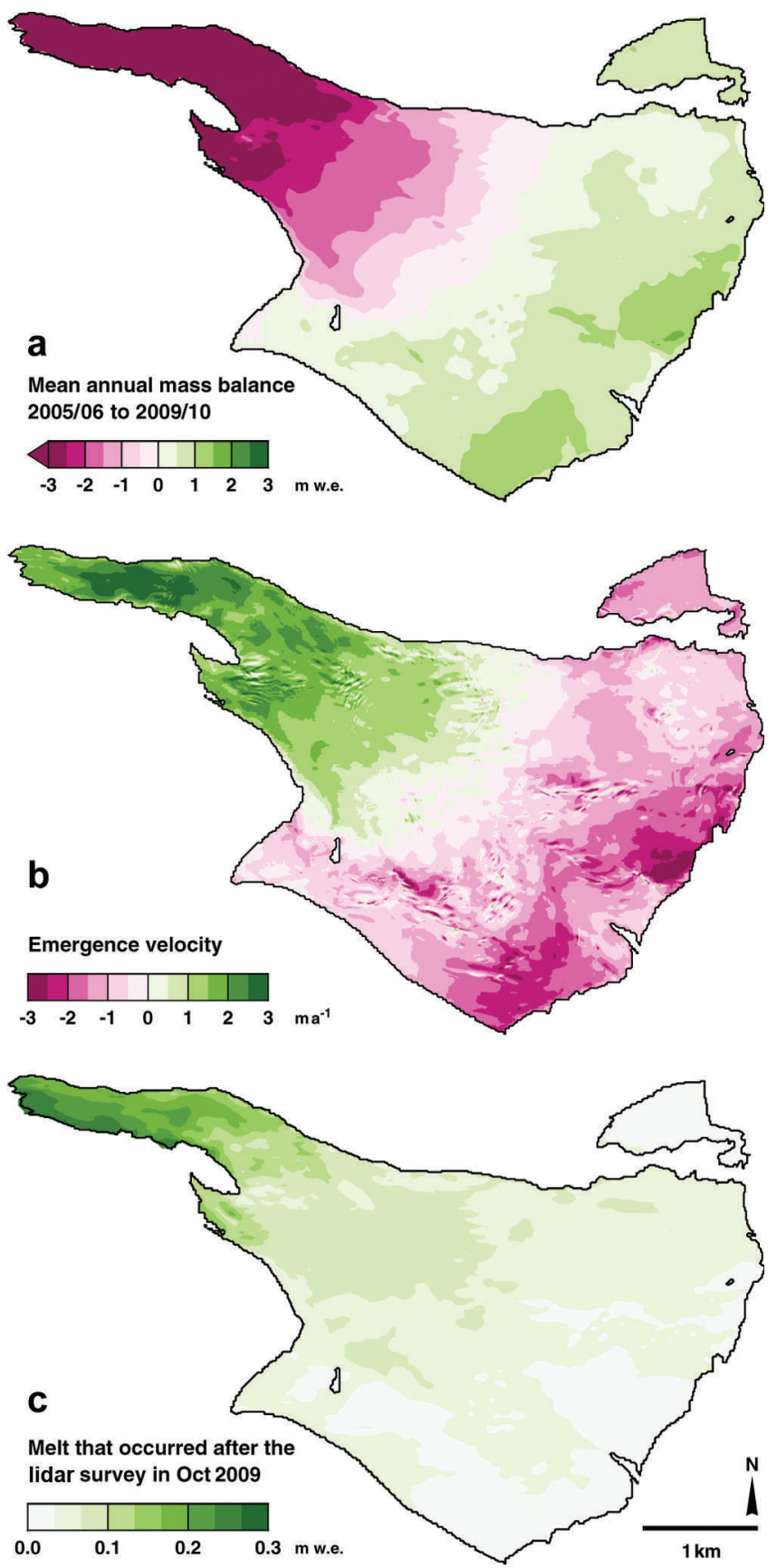

Fig. 6. (a) Mean annual mass balance 2005/06 to 2009/10. (b) Vertical component of ice flow (emergence velocity), derived from the mean annual mass balance and observed geometry changes. A positive velocity is directed upwards (emergence). (c) Modelled melt that occurred after the lidar DEM was generated in October 2009.

zero when the effect from firn compaction is omitted (Fig. 6b). This is a result of the cumulative annual mass balance, $b_{\mathrm{a}}$, corresponding to the geodetic mass change, $\Delta z$, in Eqn (2). This estimation refers to the displacement of the summer surface, so a spatial average different from zero would imply a glacier volume change due to ice flow.

Because the time-step from October 2009 to April 2010 corresponds to a fraction rather than a full year, the annual average emergence velocity must be scaled to fit this timespan. However, the choice of this scaling must integrate temporal variations of the respective processes. Changes in the glacial drainage system affect ice-flow characteristics and are known to show seasonality (Iken and Truffer, 1997). 


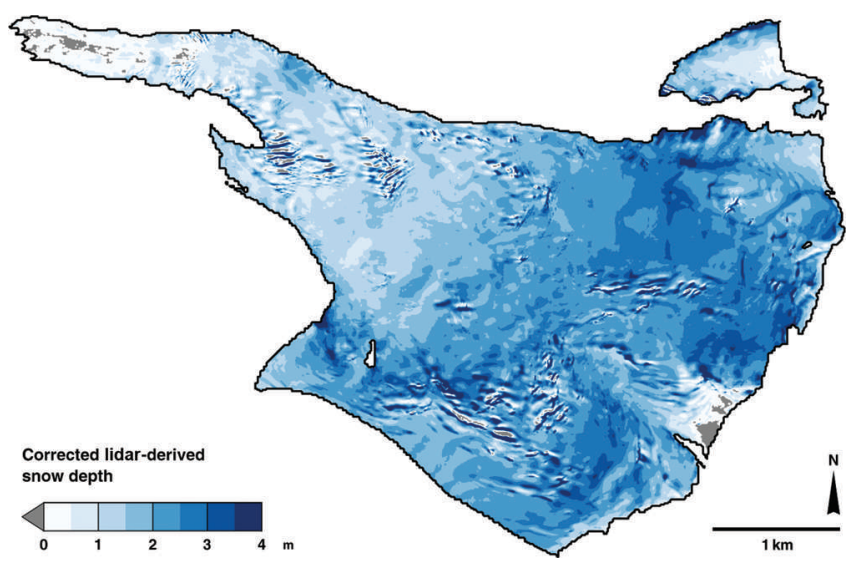

Fig. 7. Snow depth derived from lidar DEMs corrected for emergence velocity, firn compaction and autumn melt (Eqn (5)). Grey shading indicates negative values.

Furthermore, the densification of firn depends on its temperature and the accumulation in subsequent years. Thus, we introduced a tuning factor, $f=0.795$, to account for seasonal and annual variations in ice-flow velocity and firn compaction rates. This factor $f$ was derived by minimizing the square error of the resulting snow depth to the in situ snow probings (see Discussion).

The melt occurring after the lidar survey in October 2009 was estimated using a distributed temperature-index model (Hock, 1999; Huss and others, 2009). The model was driven by daily temperature and precipitation obtained from a weather station at Zermatt $(6 \mathrm{~km}$ distance from the glacier tongue, $1638 \mathrm{~m}$ a.s.l.). The resulting cumulative melt, $\mathrm{m}$ ( $m$ ice eq.), was added to the difference, $\Delta h$, of the two lidar DEMs in October and April. On the glacier tongue it had the highest impact of up to $0.3 \mathrm{~m}$ (Fig. 6c). Together with the scaled correction for emergence velocity and firn compaction, $v_{z}$, this provides a corrected snow depth, $d$, (Fig. 7) as

$$
d=\Delta \mathrm{h}+m-f \cdot v_{\mathrm{z}} .
$$

The elevation-dependent distribution of snow depth derived from the extrapolated snow probings and lidardifferencing underlines the need for this correction (Fig. 8). The uncorrected lidar-derived snow depth is strongly affected by emergence velocity and firn compaction. After application of the correction the two methods show good agreement in most of the elevation bands.

The presented method to derive the snow accumulation distribution from lidar-differencing requires, in addition to the two DEMs, long-term annual mass-balance and geometry changes and in situ measurements of snow depth. This expense can be reduced if the geometry changes can be omitted, implying that the glacier is in equilibrium. Furthermore, information about the vertical displacement of the glacier surface could be derived, for example, from GPS measurements or triangulation of the positions of the commonly used mass-balance stakes. If the vertical displacement of the last summer surface during the winter is known, at least for a few points, the scaling of the correction and its calibration with in situ snow probings are redundant. Otherwise, an estimation of snow depth is necessary to scale the correction to fit the time-span between the generation of the two DEMs. To provide a stable fit, these estimations should preferably exist for areas where the annual emergence velocity is high, i.e. on the glacier tongue and in the upper

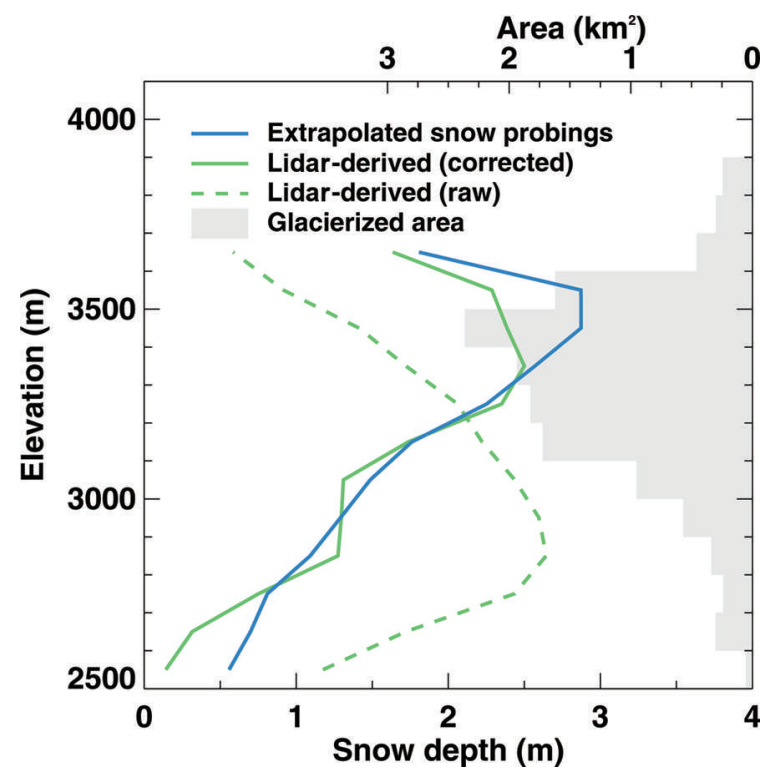

Fig. 8. Vertical distribution of mean snow depth in $100 \mathrm{~m}$ elevation bands derived from extrapolated snow probings, raw lidardifferencing and lidar-differencing corrected for emergence velocity, firn compaction and autumn melt (Eqn (5)). The distribution of the glaciated area is shown in grey.

accumulation area, but are not required to cover the glacier representatively.

\section{RESULTS}

The three datasets differ in the type of spatial information they present. GPR profiles provide snow depth in linear transects and do not cover the entire glacier representatively. To compare GPR with in situ probings and lidar-derived snow depth, the probings must be extrapolated to achieve a least common spatial coverage of all three datasets. None of them is considered to be the ground reference, to allow full advantage to be taken of their simultaneous availability.

All three methods reveal the increase in snow depth with elevation. They disagree in crevassed areas, where the determination of a meaningful snow depth value is hampered by its large variability within the GPR footprint and movement of the crevasses with time that affects the local lidar-derived snow depth (Fig. 9). Both lidar and GPR are able to resolve the small-scale variability of snow depth, to a certain degree, due to their spatial resolution. Obviously, this is not the case for the spatially extrapolated snow probings (Fig. 9). Along the GPR profiles, with a constant spacing of $1 \mathrm{~m}$ between measurements, the rootmean-square error (rmse) and bias in the datasets is calculated using the closest gridpoints of the snow depth maps from lidar and extrapolated probings. In this comparison, the extrapolated snow probings reveal a higher, and lidar-differencing a lower, snow depth than GPR (Table 1). The generally high rmse of $0.39-0.62 \mathrm{~m}$ between the methods can partly be explained by the extrapolation scheme for the snow probings and the mass balance underlying the correction of lidar snow depth. Further, due to the high resolution of the lidar DEMs, the horizontal ice flow adds a local stochastic uncertainty by shifting smallscale surface features, including crevasses, to neighbouring gridcells. The smallest rmse was found to be $0.39 \mathrm{~m}$ between 


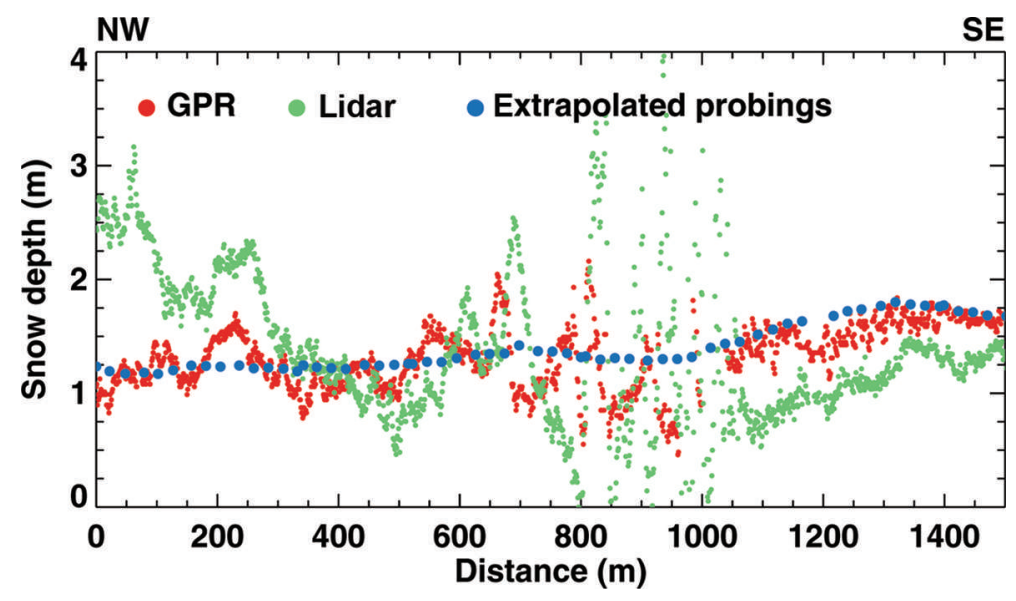

Fig. 9. Snow depth obtained from GPR and at the nearest gridcells of the extrapolated snow probings and corrected lidar DEM-differencing along the first $1500 \mathrm{~m}$ of GPR profile 1, ranging from 2880 to $3080 \mathrm{~m}$ a.s.I. (Fig. 1).

the extrapolated probings and lidar-derived snow depth. This is probably because of the fitting of the correction to the snow probings. Differences of the in situ snow probings (not extrapolated) to GPR and lidar will be highlighted in the Discussion (Figs 12 and 13).

The traditional glaciological approach, using extrapolated snow probings and snow density in the elevation bands, provides a winter mass balance of Findelengletscher of $0.78 \mathrm{~m}$ w.e. The lidar-differencing yields a similar result of $0.72 \mathrm{~m}$ w.e. Although the point snow probings were used for the extrapolation and the scaling of the correction for ice emergence velocity, the good agreement in winter mass balance underlines the high potential of deriving snow depth by lidar DEM-differencing.

The extrapolated snow probings allow a spatial comparison with the lidar-derived snow depth distribution to be made. Because the in situ snow probings were used to find the optimal scaling factor, $f$, of the lidar correction, the two datasets are not fully independent. However, the linear scaling of the correction (Eqn (5)), which has a strong altitudinal gradient (Fig. 6b), affects the distribution of snow between the ablation and accumulation areas and, only to a lesser extent, its variability at a smaller scale. Furthermore, a similar value of $f$ would have been found using the GPR snow depth instead of the in situ probings (see Discussion). Thus, the dependence of the two datasets plays a minor role when comparing the spatial snow accumulation distribution. The two methods show good agreement for large parts of the glacier (Fig. 10). They disagree on snow depth for marginal regions of the glacier, especially in areas that were not covered by snow probings or mass-balance measurements and, thus, were not adequately represented in the respective spatial extrapolation. Particularly, this involves parts of the accumulation area and the uppermost part of the glacier, where wind erosion of snow is most pronounced.

The availability of distributed snow depth data and highresolution DEMs allowed us to investigate snow depth distribution with surface topography, such as elevation, slope and curvature. While elevation affects the amount of precipitation, slope and curvature were taken as proxies for local variations in snow depth due to preferential deposition and redistribution (Huss and others, 2008; Lehning and others, 2008). We followed previous studies that used multiple linear regression (Schmidt and others, 2009;
Farinotti and others, 2010) in the form

$$
d=\beta_{0}+\beta_{1} x_{1}+\beta_{2} x_{2}+\beta_{3} x_{3}
$$

to estimate snow depth, $d$. All grids were upscaled to a $10 \mathrm{~m} \times 10 \mathrm{~m}$ cell size to reduce computation time. The October 2009 lidar DEM provided elevation, $x_{1}$, and allowed computation of slope, $x_{2}$, and curvature, $x_{3}$, (Zevenbergen and Thorne, 1987). The coefficients $\beta_{i}$ were found by least-squares estimation from the lidar-derived distributed snow depth (Fig. 7). Curvature was derived within a radius of $70 \mathrm{~m}$ around each gridcell. Although not supported by any physical process, this radius provided the highest correlation with snow depth. A positive sign indicates a convex surface. Crevassed areas were masked because the lidar-derived snow depth gives unreliable results in these regions.

Over the entire glacier, correlation of snow depth with elevation is $r=0.40$, while slope $\left(95 \%\right.$ central range: $\left.3-31^{\circ}\right)$ has little influence $(r=0.20)$. Higher snow depths are found in areas with a concave curvature $(r=-0.27)$. This multiple linear regression model can only partially explain snow depth variability $(r=0.51, p<0.001$ for all given correlations). This is in line with the findings of Farinotti and others (2010). They point out that this cannot be interpreted as absence of an influence of these factors on snow depth, as it can be nonlinear or masked by other factors, such as variations in wind speed and its prevailing direction (Purves and others, 1998; Plattner and others, 2006).

From previous studies it is known that deposition and redistribution of snow is largely determined by the interplay

Table 1. Root-mean-square error (rmse) and bias of extrapolated snow probings (ESP), lidar and GPR-derived snow depth along the GPR profile lines (crevassed areas masked, profile lines shown in Fig. 1)

\begin{tabular}{lccc}
\hline$A$ & $B$ & rmse & Bias $A-B$ \\
& & $\mathrm{~m}$ & $\mathrm{~m}$ \\
\hline GPR & lidar & 0.623 & 0.107 \\
ESP & lidar & 0.385 & 0.164 \\
GPR & ESP & 0.565 & -0.057 \\
\hline
\end{tabular}




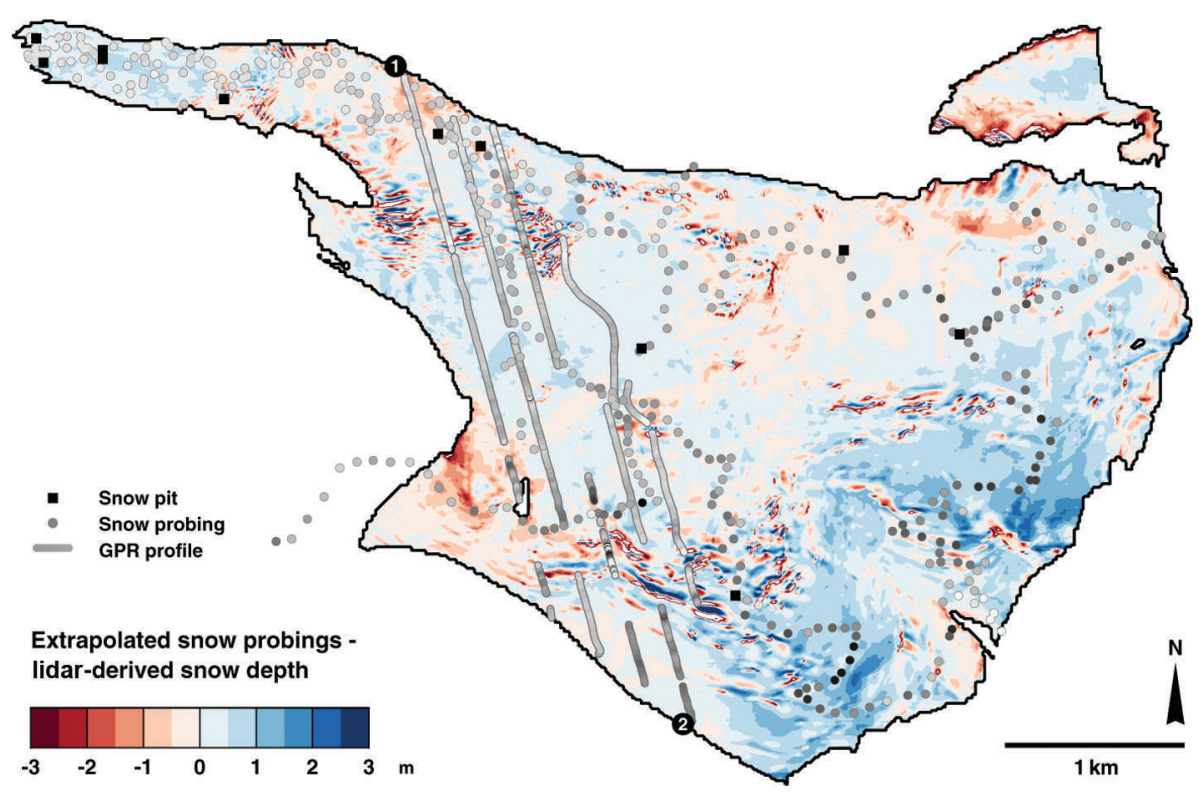

Fig. 10. Difference of corrected lidar-derived to extrapolated snow depth from probings. Blue indicates an underestimation, and red an overestimation, of lidar-derived snow depth compared with the extrapolated probings.

of wind and surrounding topography (Liston and Sturm, 1998; Winstral and Marks, 2002; Lehning and others, 2008; Dadic and others, 2010a). In the regression this was incorporated as curvature on the small scale of a $70 \mathrm{~m}$ radius. Obviously, this approach does not respect actual local wind fields that are also formed by surface features on larger scales. To account for spatial variations in the influence of the selected variables, we introduced a zonal regression using the same variables but restricted to a $2 \mathrm{~km} \times 2 \mathrm{~km}$ moving box around each gridcell of the lidarderived snow depth map. By running a separate regression for the surroundings of each gridcell, we derived a smoothed map of the strength of the linear dependence of snow depth on the selected variables (Fig. 11).

The zonal regression shows a better performance than the regression for the entire glacier and allows a more detailed interpretation. The multiple linear correlation coefficient ranges from $r=0.22$ on the upper glacier tongue (2900 ma.s.l.) and in the lower accumulation area (3250-3350 ma.s.l.) to $r=0.83$ in the upper ablation area (3100-3200 ma.s.l.) and upper accumulation area (>3450 ma.s.I.) (Fig. 11c). If instead the same number of gridcells is randomly chosen from across the glacier, the multiple linear correlation coefficient is $r=0.45 \pm 0.01$. The size of the moving box determines the smoothness and the data range of the correlation coefficient maps in the expected way (e.g. $0.18 \leq r \leq 0.94$ for $1 \mathrm{~km} \times 1 \mathrm{~km}$, $0.30 \leq r \leq 0.83$ for $3 \mathrm{~km} \times 3 \mathrm{~km}$ ). Thus, the variable correlation coefficients for the zonal regression can be attributed to spatial variations in the relation of snow depth to the examined topographic variables. While the upper glacier tongue might show overestimation of lidar-derived snow depth, as indicated by GPR and snow probings (Figs 9 and $10)$, the weak performance in the lower accumulation area is related to the changing sign in the correlation with elevation. Zonal correlation with elevation (Fig. 11a) highlights that a linear elevation gradient is not representative for the entire glacier. Instead, the correlation of elevation and snow depth changes sign at high altitudes. For slope, the correlation is less than $|r|=0.38$ for $75 \%$ of the glaciated area and also changes to a negative sign at high altitudes ( $p<0.001$ for all correlations). At the same time, a regression over the whole of this area of negative zonal correlation with slope gives $r=-0.03$. Curvature yields strictly negative correlations that are generally stronger at higher altitudes (Fig. 11b). However, the effect of curvature on snow depth is not restricted to the $70 \mathrm{~m}$ scale that is used here and can thus be underestimated by the regression.

For elevation, slope and curvature, the effect on snow depth is not constant over the entire glacier. This is likely to be linked to variations in wind speed and exposure that are controlled by the surrounding topography. Therefore, elevation, slope and fixed-scale curvature alone cannot sufficiently explain snow depth distribution in a linear regression model for the entire glacier, but can within subregions of similar influence of wind fields.

\section{DISCUSSION}

\section{Systematic bias in the snow probings dataset}

In contrast to the snow probings, GPR provides snow depth as continuous profiles, instead of discrete point values. Thus, we evaluated a potential difference of the snow probings from the GPR data as a function of distance between the measurements. Therefore, all possible pairs of one measurement from each method were identified. Mean and standard deviation of the difference between every two measurements were obtained for all pairs with less than a critical distance, increased in $10 \mathrm{~m}$ steps. This allows a comparison of the two datasets to be made, despite the variable distance between the snow probings and the GPR profiles.

A good agreement between the two datasets is found where the distance between snow probings and GPR profiles is small (Fig. 12), and variability is of the same order within multiple probings as at individual locations $(0.13 \mathrm{~m})$. However, variability not only increases with distance, but the snow probings exceed the GPR-derived snow depth. This becomes important at distances $>30 \mathrm{~m}$ and indicates that the analysed subsets of the two methods cover different 

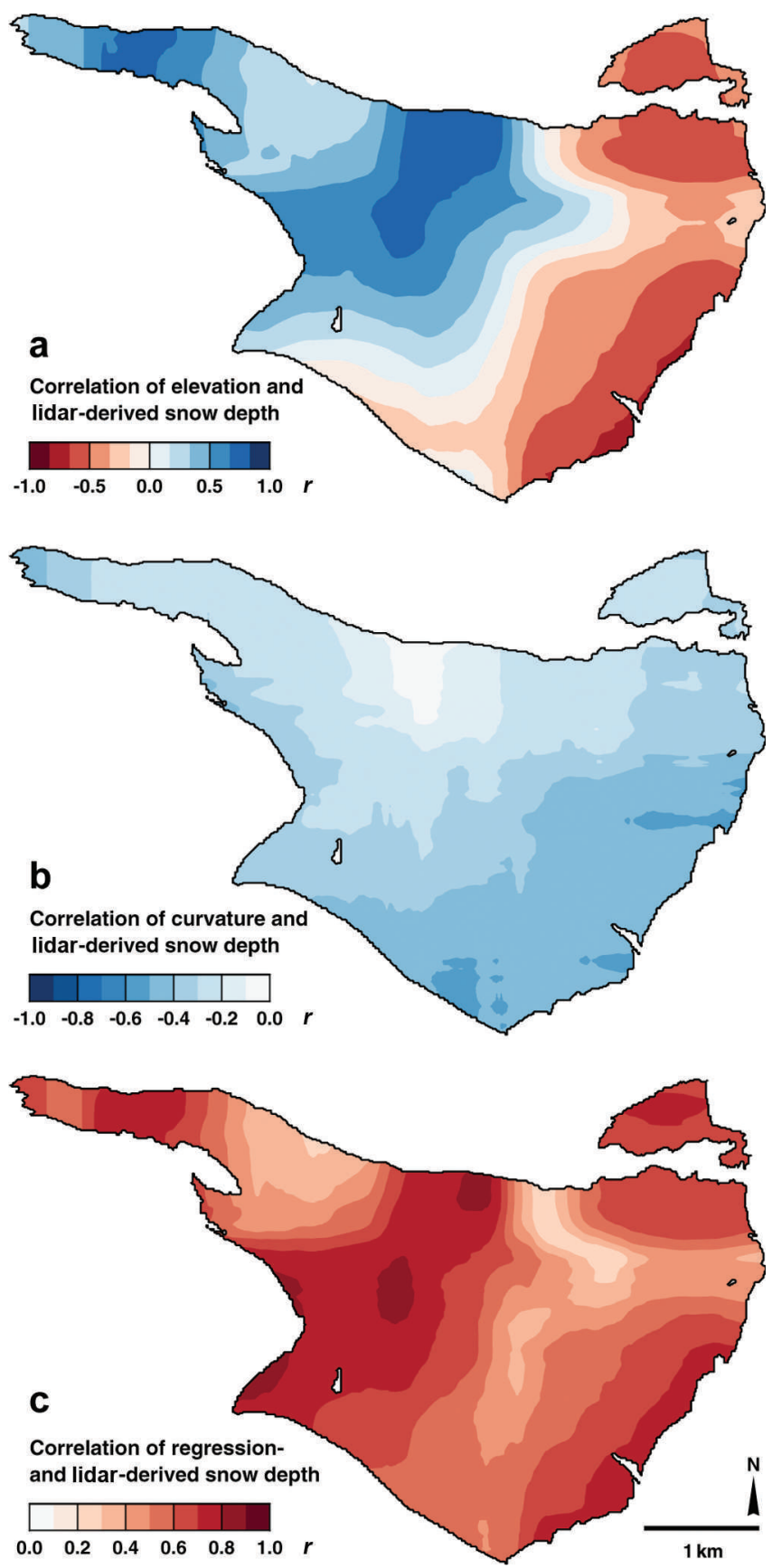

Fig. 11. Correlation of lidar-derived snow depth with (a) elevation, (b) curvature $(70 \mathrm{~m}$ scale) and (c) regression-derived snow depth for the surrounding $2 \mathrm{~km} \times 2 \mathrm{~km}$ box of each gridcell.

regions of snow accumulation. We interpret this distancedependent deviation between the datasets as a systematic bias in the in situ measurements that might be explained by either one or both of these processes: (1) the GPR profiles cover parts of the glacier surface that are inaccessible and are therefore not represented in the snow probings and/or (2) the walking path corresponding to the snow probings inadvertently avoided ridges and steeper parts of the glacier that are prone to wind erosion and thus shallower snow depth, and rather was attracted by depressions, shallow troughs or flat areas in which snow tends to be deposited.

\section{Uncertainties in GPR-derived snow depth}

GPR provides estimates of snow depth that are not affected by glacier dynamics, such as firn compaction or ice flow.

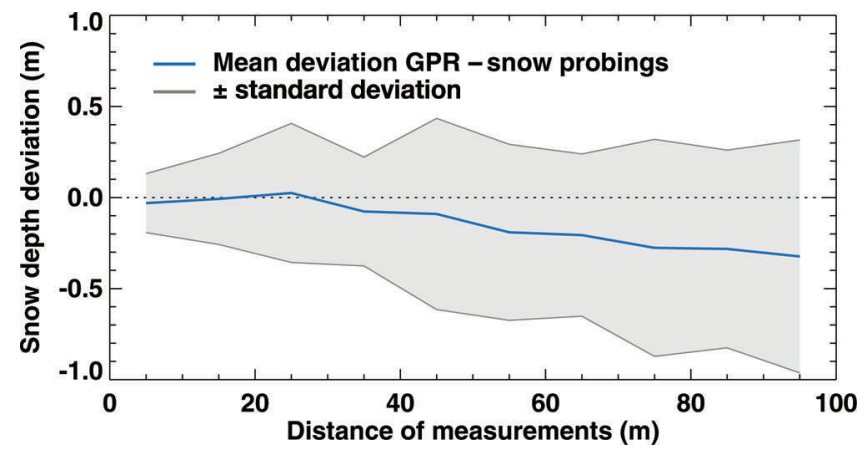

Fig. 12. Distance-dependent deviation of GPR-derived snow depth for probings, shown as mean and standard deviation of all measured deviations within each $10 \mathrm{~m}$ class. Each class contains all possible measurement pairs of the two datasets with a distance shorter than the upper class limit.

Nevertheless, uncertainties that arise from the choice of radio-wave velocity and the practical vertical resolution of the radargrams need to be taken into account. Also, it should be noted that the accuracy of the observer when digitizing the reflectors could play a role that cannot be exactly quantified.

The resolution of the GPR data limits the accuracy of recognized reflector travel times. It depends on the signal bandwidth, that can be approximated by the centre frequency for most GPR systems. It is typically estimated to be about half the wavelength, $\lambda$, but depends on the signal-to-noise ratio (Jol, 2009). Thus, in the given case with a frequency of $500 \mathrm{MHz}$ and a velocity of $0.229 \mathrm{~m} \mathrm{~ns}^{-1}$, the vertical resolution is $\sim \lambda / 2=0.23 \mathrm{~m}$.

As shown above, the velocity of the radar pulse depends on the characteristics of the snowpack. For snow density, the standard deviation of $21 \mathrm{~kg} \mathrm{~m}^{-3}$ from snow pits where more than one density profile is available is used as an estimate of the measurement accuracy. The total standard deviation of measured density from the area-weighted mean $\left(68 \mathrm{~kg} \mathrm{~m}^{-3}\right)$ accounts for uncertainties in the density extrapolation method and the use of a constant density. Using Eqn (1), the related total standard error in radio-wave velocity is $\pm 0.011 \mathrm{~m} \mathrm{~ns}^{-1}$. By linearity, the effect on the resulting snow depth then is $\pm 4.7 \%$.

For the computation of radio-wave velocity we assumed the snowpack to be dry along the GPR profiles. Although this was in line with observations during fieldwork, from guideline values (e.g. Fierz and others, 2009) a water content of $<3 \%$ vol. cannot be ruled out. Due to the high permittivity of water, this could have a considerable influence on the radio-wave velocity in the snowpack. Based on numerous sets of measurements, Frolov and Macheret (1999) compute the increase in dielectric permittivity, $\Delta \varepsilon^{\prime}$, due to the relative water content, $\theta$, as

$$
\Delta \varepsilon^{\prime}=16.7 \theta+42.5 \theta^{2} .
$$

Thus, liquid water content of up to $3 \%$ could reduce the radio-wave velocity from $0.229 \mathrm{~m} \mathrm{~ns}^{-1}$ to $0.199 \mathrm{~m} \mathrm{~ns}^{-1}$ by causing a higher dielectric permittivity of the snowpack. For the resulting snow depth this relative change of up to $-13.1 \%$ could make a significant difference but cannot be determined exactly. Furthermore, the water content varies not only with depth in the snowpack but also spatially (Techel and Pielmeier, 2011). This makes it difficult to 

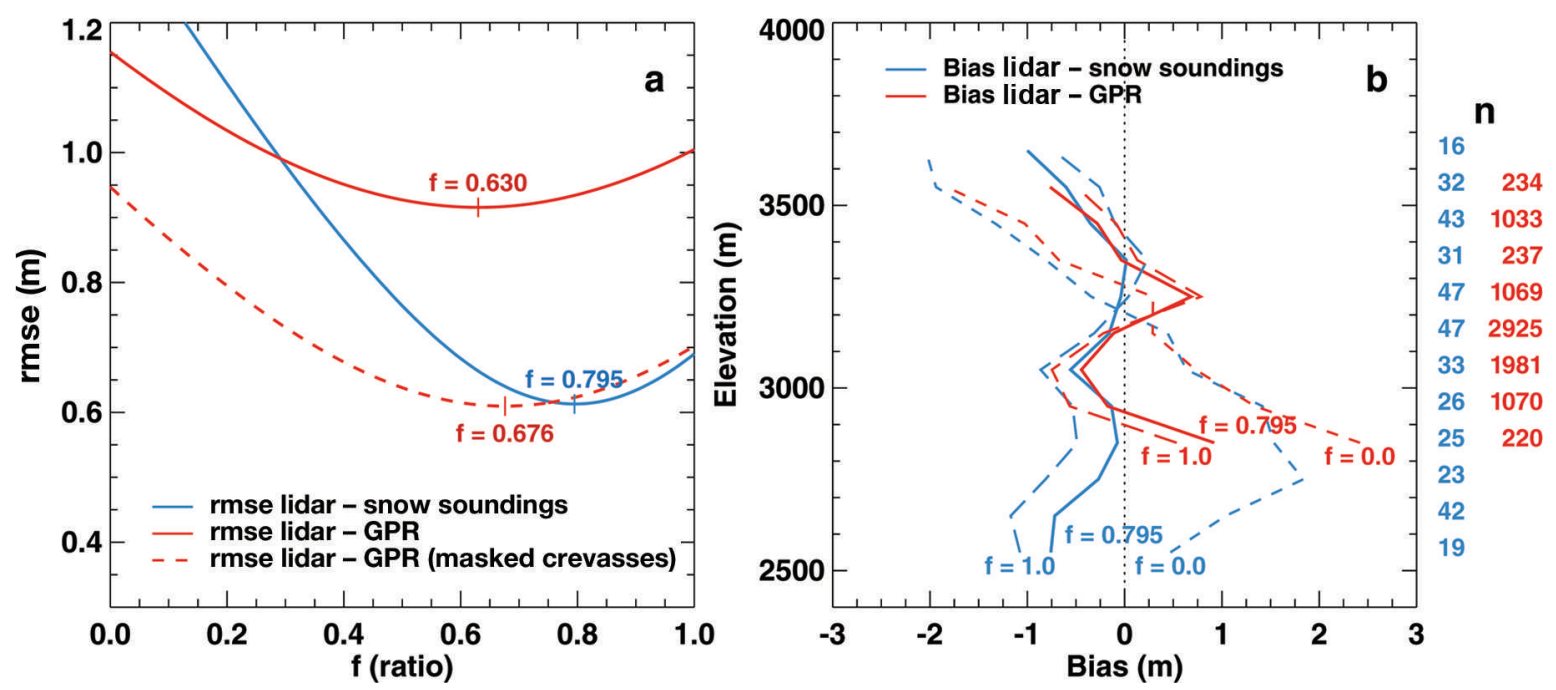

Fig. 13. (a) Determination of the optimal scaling factor, $f$, of the annual vertical surface velocity by minimizing the rmse of lidar-derived snow depth to GPR and in situ probings. (b) Elevation-dependent bias in lidar- to GPR-derived snow depth (red) and probings (blue) for different choices of the scaling factor, $f$, shown as mean deviation from $n$ measurements within $100 \mathrm{~m}$ elevation bands.

incorporate this factor in the analysis. During fieldwork, the snowpack in the lower parts of the glacier (i.e. the tongue) showed evidence of some liquid water content, whereas the snow pits in the elevation range covered by GPR profiles were dry, due to lower temperatures. Furthermore, the velocity of $0.229 \mathrm{~m} \mathrm{~ns}^{-1}$ which is used in this study indicates good agreement with the in situ snow probings (Fig. 12). A reduced velocity would even increase the already negative deviation from the extrapolated snow probings (Table 1 ). Thus, the effect is likely to be small.

\section{Ice-flow dynamics affect lidar-derived snow depth}

From the vertical distribution of mean snow depth (Fig. 8) it is obvious that the correction for emergence velocity and firn compaction is necessary when evaluating snow depth distribution from repeated lidar DEMs. As described, the resulting vertical velocity of the autumn glacier surface was estimated as an annual average from long-term massbalance and geometry changes. Since the temporal difference of the DEMs did not correspond to a full year and to account for interannual variations, the correction was scaled by a factor $f$ (Eqn (5)).

Earlier studies interpreted seasonal variations in the iceflow dynamics of Findelengletscher to be a result of changes in the subglacial drainage system (Iken and Bindschadler, 1986; Iken and Truffer, 1997). The horizontal ice-flow velocity was measured by triangulation at several points on the glacier tongue and revealed a counter-intuitive behaviour. Peak velocity in May and June was followed by a rapid decrease. Starting in October and over the whole winter, horizontal velocity increased (Iken and Truffer, 1997). Although these results cannot be directly transferred to the current situation or individual years, using the halfyear fraction $f=0.5$ of $v_{z}$ to cover the time-span from October 2009 to April 2010 is inappropriate. Instead, the optimal fraction of $f=0.795$ is found iteratively by minimizing the rmse of snow depth, $d$, to the available in situ data from snow probings. The GPR data were not chosen as a reference here because they do not cover the glacier representatively. Nonetheless, the optimal $f$ would correspond well if it were instead obtained with the GPRderived snow depth ( $f=0.676$; Fig. 13a).
Comparison of lidar-derived snow depth with GPR and probings for different values of $f$ shows the strong elevationdependent bias in the uncorrected data ( $f=0$; Fig. 13b). With the correction scaled by $f=0.795$ to best fit the snow probings, the imbalance of snow depth overestimation in the ablation area and underestimation in the accumulation area is compensated. Underestimation of snow depth on the lower glacier tongue and in the upper accumulation area might be explained by a local overestimation in the correction for the vertical surface velocity.

The high value of $f$ compared with the expected half-year fraction cannot be explained by seasonal variations in iceflow velocity alone. Since the correction is based on average mass-balance and geometry changes from a 5 year period, short-term fluctuations are not adequately represented. These can be due to changes in ice-flow velocity but also to variations in the mass balance in recent years that affect firn compaction rates in the accumulation area. The glaciological time series shows a mass balance of $+0.83 \mathrm{~m}$ w.e. for the accumulation area of Findelengletscher in 2009. For the other years that were used for the calculation of the correction (2005-10), values range from +0.58 to $+0.65 \mathrm{~m}$ w.e. Thus, firn compaction played a larger role in the period October 2009 to April 2010 than is estimated in the correction, leading to a higher value of $f$ when the correction is fitted to the snow probings.

By calibrating the scaling factor, $f$, with the snow depth from probings, the correction of the lidar-derived snow depth takes the interannual and seasonal variations in emergence velocity and firn compaction into account. However, the two processes are independent of each other, do not affect the same area and probably do not vary synchronously. Therefore, the scaling factor, $f$, represents a tuning parameter that integrates all influential processes and allows reconciling the correction of raw lidar-derived snow depth with the individual conditions during the time-span from October 2009 to April 2010.

\section{CONCLUSIONS}

We have discussed measurements of snow accumulation distribution in April 2010 on Findelengletscher from 
403 snow probings, $12.7 \mathrm{~km}$ of GPR profiles and differencing of two lidar DEMs. The lidar-derived elevation change must be corrected for the glacier emergence velocity and firn compaction. We successfully obtained this correction from long-term mass-balance and geometry changes. All three datasets reveal the general increase in snow depth with elevation. In contrast to the snow probings, GPR and lidar-differencing are able to capture its small-scale variability. Over the entire glacier, snow depth can only partially be explained by elevation, slope and curvature, since deposition and redistribution of snow is strongly determined by local wind fields. We have shown that the explanatory power of these topographic variables is significant within subregions on the glacier. Comparison between snow probings and GPR-derived snow depth indicates a bias in the dataset of snow probings that probably originates from a non-representative distribution of sampling sites.

Single-offset GPR is an effective tool for snow depth measurements that is not affected by glacier dynamics and firn compaction in the accumulation area. It is prone to few uncertainties if estimates for snow density and liquid water content exist. However, the GPR profiles should cover the glacier representatively (e.g. on a grid). Airborne data acquisition is efficient and flexible, but the Swiss telecommunication regulator (OFCOM) allows airborne use of the GPR system only under strict conditions and in uninhabited regions, such as on alpine glaciers. Thus, further technical and regulatory development is needed to fulfil the requirements of national and international authorities for future studies. Lidar provides a fully distributed set of snow depth data with very high spatial resolution, which is not achievable by the application of GPR or conventional glaciological measurements. When corrected for glacier dynamics, lidar-differencing is a powerful tool to assess snow depth distribution on alpine glaciers, but it is expensive in terms of external data requirements. In the presented comparison, the traditional approach of using snow probings remains the only method that is independent of separate input data. However, snow probings typically do not reproduce the small-scale variability of snow depth. We conclude that the choice between the presented methods should depend on the availability of in situ measurements and the desired balance between accuracy and spatially distributed data. GPR provides a compromise in both respects. It requires snow density and wetness estimations that need not necessarily be gained from in situ measurements but that determine the main uncertainties. At the same time, because it provides snow depth along linear profiles, its ability to reproduce the spatial variability lies between the probings and the fully distributed lidar-differencing scheme.

The time-matched availability of the three datasets accounts for the need to have separate data sources as a basis to evaluate the performance of individual methods. Their comparison and combination illustrates a detailed image of winter snow accumulation that benefits from each method's advantages and will provide a valuable dataset in the future to validate accumulation models of varying complexities.

\section{ACKNOWLEDGEMENTS}

We thank N. Salzmann, A. Linsbauer, H. Machguth and other members of the field team for the repeated campaigns and ongoing mass-balance measurements. Constructive comments of two anonymous reviewers helped to improve and clarify the manuscript. This study is supported by the Swiss National Science Foundation (SNSF), grant 200021_134768.

\section{REFERENCES}

Abermann J, Fischer A, Lambrecht A and Geist T (2010) On the potential of very high-resolution repeat DEMs in glacial and periglacial environments. Cryosphere, 4(1), 53-65 (doi: 10.5194/tc-4-53-2010, 2010)

Ackermann F (1999) Airborne laser scanning - present status and future expectations. ISPRS J. Photogramm. Rem. Sens, 54(2-3), 64-67 (doi: 10.1016/S0924-2716(99)00009-X)

Annan AP (1999) Practical processing of GPR data. Sensors \& Software Inc., Mississauga, Ont. http://www.ees.nmt.edu/outside/courses/Geop446/Docs/GPR_data_process.pdf

Arendt AA, Echelmeyer KA, Harrison WD, Lingle CS and Valentine VB (2002) Rapid wastage of Alaska glaciers and their contribution to rising sea level. Science, 297(5580), 382-386 (doi: 10.1126/science.1072497)

Bamber JL and Rivera A (2007) A review of remote sensing methods for glacier mass balance determination. Global Planet. Change, 59(1-4), 138-148 (doi: 10.1016/j.gloplacha.2006.11.031)

Bauder A, Funk M and Gudmundsson GH (2003) The ice-thickness distribution of Unteraargletscher, Switzerland. Ann. Glaciol., 37, 331-336 (doi: 10.3189/172756403781815852)

Cuffey KM and Paterson WSB (2010) The physics of glaciers, 4th edn. Butterworth-Heinemann, Oxford

Dadic R, Mott R, Lehning M and Burlando P (2010a) Wind influence on snow depth distribution and accumulation over glaciers. J. Geophys. Res., 115(F1), F01012 (doi: 10.1029/2009JF001261)

Dadic R, Mott R, Lehning M and Burlando P (2010b) Parameterization for wind-induced preferential deposition of snow. Hydrol. Process., 24(14), 1994-2006 (doi: 10.1002/hyp.7776)

Damm V (2004) Ice thickness and bedrock map of Matusevich Glacier drainage system (Oates Coast). Terra Antart., 11(1), 85-90

Davis JL and Annan AP (1989) Ground-penetrating radar for high-resolution mapping of soil and rock stratigraphy. Geophys. Prospect., 37(5), 531-551 (doi: 10.1111/j.1365-2478.1 989.02221.x)

Dunse T, Eisen O, Helm V, Rack W, Steinhage D and Parry V (2008) Characteristics and small-scale variability of GPR signals and their relation to snow accumulation in Greenland's percolation zone. J. Glaciol., 54(185), 333-342 (doi: 10.3189/ 002214308784886207)

Dunse T, Schuler TV, Hagen JO, Eiken T, Brandt O and Høgda KA (2009) Recent fluctuations in the extent of the firn area of Austfonna, Svalbard, inferred from GPR. Ann. Glaciol., 50, 155-162 (doi: 10.3189/172756409787769780)

Egli L, Jonas T, Grünewald T, Schirmer M and Burlando P (2012) Dynamics of snow ablation in a small Alpine catchment observed by repeated terrestrial laser scans. Hydrol. Process., 26(10), 1574-1585 (doi: 10.1002/hyp.8244)

Eisen $O$ and 15 others (2008) Ground-based measurements of spatial and temporal variability of snow accumulation in East Antarctica. Rev. Geophys., 46(RG2), RG2001 (doi: 10.1029/ 2006RG000218)

Farinotti D, Magnusson J, Huss M and Bauder A (2010) Snow accumulation distribution inferred from time-lapse photography and simple modelling. Hydrol. Process., 24(15), 2087-2097 (doi: 10.1002/hyp.7629)

Farinotti D, Usselmann S, Huss M, Bauder A and Funk M (2012) Runoff evolution in the Swiss Alps: projections for selected highalpine catchments based on ENSEMBLES scenarios. Hydrol. Process., 26(13), 1909-1924 (doi: 10.1002/hyp.8276)

Fierz C and 8 others (2009) The international classification for seasonal snow on the ground. (IHP Technical Documents in Hydrology 83) UNESCO-International Hydrological Programme, Paris 
Fisher SC, Stewart RR and Jol HM (1996) Ground penetrating radar (GPR) data enhancement using seismic techniques. J. Environ. Eng. Geophys., 1(2), 89-96 (doi: 10.4133/JEEG1.2.89)

Frolov AD and Macheret YuYa (1999) On dielectric properties of dry and wet snow. Hydrol. Process., 13(12-13), 1755-1760 (doi: 10.1002/(SICI)1099-1085(199909)13:12/13<1755::AIDHYP854>3.0.CO;2-T)

Glaciological Reports (2011) The Swiss glaciers, 2005/06-2006/07. Yearbooks of the Cryospheric Commission of the Swiss Academy of Sciences (SCNAT), 127-128. VAW-ETHZ, Zürich

Grünewald T, Schirmer M, Mott R and Lehning M (2010) Spatial and temporal variability of snow depth and ablation rates in a small mountain catchment. Cryosphere, 4(2), 215-225 (doi: 10.5194/ tc-4-215-2010)

Haeberli W and Beniston M (1998) Climate change and its impacts on glaciers and permafrost in the Alps. Ambio, 27(4), 258-265

Heilig A, Eisen O and Schneebeli M (2010) Temporal observations of a seasonal snowpack using upward-looking GPR. Hydrol. Process., 24(22), 3133-3145 (doi: 10.1002/hyp.7749)

Helfricht K, Schöber J, Seiser B, Fischer A, Stötter J and Kuhn M (2012) Snow accumulation of a high alpine catchment derived from LiDAR measurements. Adv. Geosci., 32, 31-39 (doi: 10.5194/ adgeo-32-31-2012)

Helfricht K, Kuhn M, Keuschnig M and Heilig A (2013) LiDAR snow cover studies on glacier surface: significance of snow- and ice dynamical processes. Cryosphere Discuss., 7(2), 1787-1832 (doi: 10.5194/tcd-7-1787-2013)

Helm V and 6 others (2007) Winter accumulation in the percolation zone of Greenland measured by airborne radar altimeter. Geophys. Res. Lett., 34(6), L06501 (doi: 10.1029/ 2006GL029185)

Hock R (1999) A distributed temperature-index ice- and snowmelt model including potential direct solar radiation. J. Glaciol., 45(149), 101-111

Hock R (2005) Glacier melt: a review on processes and their modelling. Progr. Phys. Geogr., 29(3), 362-391 (doi: 10.1191/ 0309133305pp453ra)

Huss M (2011) Present and future contribution of glacier storage change to runoff from macroscale drainage basins in Europe. Water Resour. Res., 47(W7), W07511 (doi: 10.1029/ 2010WR010299)

Huss M, Bauder A, Funk M and Hock R (2008) Determination of the seasonal mass balance of four Alpine glaciers since 1865 . J. Geophys. Res., 113(F1), F01015 (doi: 10.1029/2007JF000803)

Huss M, Bauder A and Funk M (2009) Homogenization of long-term mass-balance time series. Ann. Glaciol., 50(50), 198-206 (doi: 10.3189/172756409787769627)

Huss $M$ and 6 others (2013) Towards remote monitoring of subseasonal glacier mass balance. Ann. Glaciol., 54(63 Pt 1), 75-83 (doi: 10.3189/2013AoG63A427)

Iken A and Bindschadler RA (1986) Combined measurements of subglacial water pressure and surface velocity of Findelengletscher, Switzerland: conclusions about drainage system and sliding mechanism. J. Glaciol., 32(110), 101-119

Iken A and Truffer M (1997) The relationship between subglacial water pressure and velocity of Findelengletscher, Switzerland, during its advance and retreat. J. Glaciol., 43(144), 328-338

Joerg P, Morsdorf F and Zemp M (2012) Uncertainty assessment of multi-temporal airborne laser scanning data: a case study at an Alpine glacier. Remote Sens. Environ., 127, 118-129 (doi: 10.1016/j.rse.2012.08.012)

Jol HM (2009) Ground penetrating radar theory and applications. Elsevier Science, Amsterdam

Kääb A, Berthier E, Nuth C, Gardelle J and Arnaud Y (2012) Contrasting patterns of early twenty-first-century glacier mass change in the Himalayas. Nature, 488(7412), 495-498 (doi: 10.1038/nature11324)

Kanagaratnam P, Gogieneni SP, Ramasami V and Braaten D (2004) A wideband radar for high-resolution mapping of near-surface internal layers in glacial ice. IEEE Trans. Geosci. Remote Sens., 42(3), 483-490 (doi: 10.1109/TGRS.2004.823451)

Kaser G, Cogley JG, Dyurgerov MB, Meier MF and Ohmura A (2006) Mass balance of glaciers and ice caps: consensus estimates for 1961-2004. Geophys. Res. Lett., 33(19), L19501 (doi: 10.1029/2006GL027511)

Kohler J, Moore J, Kennett M, Engeset R and Elvehøy H (1997) Using ground-penetrating radar to image previous years' summer surfaces for mass-balance measurements. Ann. Glaciol., 24, 355-360

Kovacs A, Gow AJ and Morey RM (1993) A reassessment of the insitu dielectric constant of polar firn. CRREL Rep. 93-26

Kruetzmann NC, Rack W, McDonald AJ and George SE (2011) Snow accumulation and compaction derived from GPR data near Ross Island, Antarctica. Cryosphere, 5(2), 391-404 (doi: 10.5194/tc-5-391-2011)

Lalumiere L and Prinsenberg S (2009) Integration of a helicopterbased ground penetrating radar (GPR) with a laser, video and GPS system. In Chung JS, Prinsenberg S, Hong SW and Nagata S eds. Proceedings of the 19th International Offshore and Polar Engineering Conference, 21-26 June 2009, Osaka, Japan, Vol. 1. International Society of Offshore and Polar Engineers, Cupertino, CA, 658-665

Lehning M, Löwe H, Ryser M and Radeschall N (2008) Inhomogeneous precipitation distribution and snow transport in steep terrain. Water Resour. Res., 44(W7), W07404 (doi: 10.1029/ 2007WR006545)

Liston GE and Sturm M (1998) A snow-transport model for complex terrain. J. Glaciol., 44(148), 498-516

Machguth H (2008) On the use of RCM data and gridded climatologies for regional scale glacier mass balance modeling in high mountain topography: the example of the Swiss Alps. (PhD thesis, University of Zürich)

Machguth H, Paul F, Hoelzle M and Haeberli W (2006a) Distributed glacier mass-balance modelling as an important component of modern multi-level glacier monitoring. Ann. Glaciol., 43, 335-343 (doi: 10.3189/172756406781812285)

Machguth H, Eisen O, Paul F and Hoelzle M (2006b) Strong spatial variability of snow accumulation observed with helicopterborne GPR on two adjacent Alpine glaciers. Geophys. Res. Lett., 33(13), L13503 (doi: 10.1029/2006GL026576)

Machguth H, Paul F, Kotlarski S and Hoelzle M (2009) Calculating distributed glacier mass balance for the Swiss Alps from regional climate model output: a methodical description and interpretation of the results. J. Geophys. Res., 114(D19), D19106 (doi: 10.1029/2009JD011775)

Marchand W-D, Killingtveit $\AA$, Wilén P and Wikström P (2003) Comparison of ground-based and airborne snow depth measurements with georadar systems, case study. Nord. Hydrol., 34(5), 427-448 (doi: 10.2166/nh.2003.025)

Marshall H-P and Koh G (2008) FMCW radars for snow research. Cold Reg. Sci. Technol., 52(2), 118-131 (doi: 10.1016/ j.coldregions.2007.04.008)

Østrem G and Brugman M (1991) Glacier mass-balance measurements: a manual for field and office work. (NHRI Science Report 4) Environment Canada. National Hydrology Research Institute, Saskatoon, Sask

Plattner Ch, Braun LN and Brenning A (2006) Spatial variability of snow accumulation on Vernagtferner, Austrian Alps, in winter 2003/04. Z. Gletscherkd. Glazialgeol., 39, 43-58

Plewes LA and Hubbard B (2001) A review of the use of radio-echo sounding in glaciology. Progr. Phys. Geogr., 25(2), 203-236 (doi: 10.1177/030913330102500203)

Purves RS, Barton JS, Mackaness WA and Sugden DE (1998) The development of a rule-based spatial model of wind transport and deposition of snow. Ann. Glaciol., 26, 197-202

Robin GdeQ, Evans S and Bailey JT (1969) Interpretation of radio echo sounding in polar ice sheets. Philos. Trans. $R$. Soc. London, Ser. A, 265(1166), 437-505 (doi: 10.1098/rsta. 1969.0063) 
Salzmann N, Machguth H and Linsbauer A (2012) The Swiss Alpine glaciers' response to the global ' $2{ }^{\circ} \mathrm{C}$ air temperature target'. Environ. Res. Lett., 7(4), 044001 (doi: 10.1088/1748-9326/7/4/ 044001)

Schmidt S, Weber B and Winiger M (2009) Analyses of seasonal snow disappearance in an alpine valley from micro- to mesoscale (Loetschental, Switzerland). Hydrol. Process., 23(7), 1041-1051 (doi: 10.1002/hyp.7205)

Solomon S and 7 others eds. (2007) Climate change 2007: the physical science basis. Contribution of Working Group I to the Fourth Assessment Report of the Intergovernmental Panel on Climate Change. Cambridge University Press, Cambridge

Techel F and Pielmeier C (2011) Point observations of liquid water content in wet snow - investigating methodical, spatial and temporal aspects. Cryosphere, 5(2), 405-418 (doi: 10.5194/tc-5405-2011)

Ulriksen P (1982) Application of impulse radar to civil engineering. (PhD thesis, Lund University of Technology)
Wehr A and Lohr U (1999) Airborne laser scanning - an introduction and overview. ISPRS J. Photogramm. Rem. Sens, 54(2), 68-82 (doi: 10.1016/S0924-2716(99)00011-8)

Winstral A and Marks D (2002) Simulating wind fields and snow redistribution using terrain-based parameters to model snow accumulation and melt over a semi-arid mountain catchment. Hydrol. Process., 16(18), 3585-3603 (doi: 10.1002/hyp.1238)

Yankielun N, Rosenthal W and Davis RE (2004) Alpine snow depth measurements from aerial FMCW radar. Cold Reg. Sci. Technol., 40(1-2), 123-134 (doi: 10.1016/j.coldregions.2004.06.005)

Zemp M, Hoelzle M and Haeberli W (2009) Six decades of glacier mass-balance observations: a review of the worldwide monitoring network. Ann. Glaciol., 50(50), 101-111 (doi: 10.3189/ 172756409787769591)

Zevenbergen LW and Thorne CR (1987) Quantitative analysis of land surface topography. Earth Surf. Process. Landf., 12(1), 47-56 (doi: 10.1002/esp.3290120107)

MS received 22 January 2013 and accepted in revised form 2 September 2013 